\title{
PENGARUH PENGGUNAAN METODE NHT (NUMBERED HEAD TOGETHER) TERHADAP HASIL BELAJAR MATEMATIKA SISWA KELASVII MTS. NW BONJERUK TAHUN PELAJARAN 2016/2017
}

\author{
Sabrun \\ Dosen Pendidikan Matematika, FPMIPA, IKIP Mataram \\ e-mail: jhonbruner@gmail.com
}

\begin{abstract}
Abstact; Result of observation early which have been conductedin class of VII MTs NW Bonjeruk obtained that result learn student mathematics use discourse method. One of the method which on the market is type cooperative method of Numbered Head Together(NHT). This Research aim to to know influence of usage of method of Numbered Head Together(NHT) to result learn student mathematics. Research type the used is type research of experiment with experiment quasi desain. Population in this research is all class student of VIIMTS. NW Bonjeruk amounting to 27 people. Data collecting technique in this research istes. Data analysis which is used in this research is by using test of $t$ test. Result of research which is obtained in this research is after analysed with test of $t$ test, obtained by $t$ count calculate 7,41 and $t$ of is tables atdk $=n-2=27-2=25$ with level of signifikansi $5 \%$ and obtained by $t$ of tables of equal to 2,06 thereby $t$ count calculate $>t$ of tables of. Its meaning of hypothesis of Ho refused and Ha accepted equally there is influence of numbered together head (NHT)of method foward studen't learn outcan in Mathematics at grade studen of VII MTs. NW Bonjerukin academi year 2016/2017.
\end{abstract}

\section{Keyword: Method study of type co-operative of Numbered Head Together,Hasil Learn}

\section{PENDAHULUAN}

Pendidikan mempunyai peranan yang sangat penting dalam menciptakan Sumber Daya Manusia yang berkualitas. Proses pendidikan yang dilaksanakan di sekolah pada dasarnya adalah kegiatan belajar mengajar yang bertujuan untuk mendapatkan hasil belajar yang optimal. Salah satu tolok ukur yang menggambarkan tinggi rendahnya keberhasilan siswa dalam belajar adalah hasil belajar. Terutama pendidikan matematika sebagai salah satu bagian dari perkembangan ilmu pengetahuan dan teknologi, harus mampu menghasilkan sumber daya manusia yang berkualitas, memiliki ketangguhan dalam berpikir dan bertindak.

Matemaika sebagai salah satu mata pelajaran yang diajarkan mulai dari jenjang pendidikan dasar, selain sebagai sumber dari ilmu lain juga merupakan sarana berpikir logis, analisis dan sistematis. Matematika harus disajikan dengan menarik dan sesuai dengan kondisi dan keadaan siswa. Hal ini tentu saja dimaksudkan agar dalam proses pembelajaran siswa lebih akif dan termotivasi untuk belajar.

Keberhasilan siswa dalam memecahkan suatu permasalahan matematika tergantung pada keberhasilannya dalam proses belajar. Strategi pembelajaran merupakan salah satu yang perlu untuk diperhatikan serta mampu untuk dimanfaatkan oleh seorang guru dalam mencapai suatu tujuan. Guru diharapkan dapat menggunakan strategi dan metode yang tepat sehingga dapat mendukung proses pembelajaran.

Berdasarkan hasil wawancara ataupun observasidi MTs. NW Bonjeruk, ditemukan bahwa minat terhadap matematika masih rendah. Hal ini dapat dilihat dalam kegiatan pembelajaran masih belum adanya keinginan siswa yang mengajukan diri untuk menjawab pertanyaan dari guru. Guru harus menunjuk siswa secara langsung untuk menjawab pertanyaannya. Selain itu kurangnya minat juga dapat dilihat dari seringnya siswa menunda-nunda untuk mengerjakan tugas yang diberikan oleh guru dan kebiasaan siswa yang hanya menunggu materi pembelajaran yang akan disampaikan oleh guru. Sebagian besar siswa belum mempunyai keinginan untuk mencari sumber materi belajar dari apa yang telah disampaikan oleh guru. Sedangkan perpustakaan sekolah telah disediakan untuk mencari sumber materi yang berkaitan dengan materi pelajaran di sekolah. Hal ini akan 
berakibat pada kemampuan siswa itu sendiri. Selain terbatasnya ilmu yang didapatkan, juga mengakibatkan pada kemampuan siswa yang dapat kurang berkembang secara maksimal.

Hal ini juga berdampak pada rendahnya hasil belajar matematika siswa. Rendahnya hasil belajar siswa yang dapat dilihat pada tabel 1.1 dibawah ini.

Tabel 1.1 Nilai Rata Raport Kelas VII MTsNW Bonjeruk Pada Mata Pelajaran Matematika

\begin{tabular}{|l|c|c|c|c|}
\hline $\begin{array}{l}\text { Tahun } \\
\text { Pelajaran }\end{array}$ & $\begin{array}{c}\text { Nilai } \\
\text { Rata- } \\
\text { Rata }\end{array}$ & $\begin{array}{c}\text { Siswa } \\
\text { yang } \\
\text { Tuntas }\end{array}$ & $\begin{array}{c}\text { SISWA } \\
\text { yang } \\
\text { Tidak } \\
\text { Tuntas }\end{array}$ & KKM \\
\hline $2014 / 2015$ & 67,96 & 18 & 20 & 70 \\
\hline $2015 / 2016$ & 67,35 & 19 & 23 & 70 \\
\hline
\end{tabular}

(Sumber: Data guru matematika MTS NW Bonjeruk)

Dari nilai tata-rata raport siswa kelas VII pada dua angkatan terakhir tersebut dapat disimpulkan bahwa pada setiap mata pelajaran matematika, siswa rata-rata mendapatkan nilai rendah atau masih dibawah KKM.

Masalah lain yang ditemukan disekolah ini adalah belum optimalnya penggunaan media dalam pembelajaran matematika yang menyebabkan siswa sering merasa bosan dalam belajar.Terlihat bahwa pada saat tugas diberikan oleh guru ada potensi siswa untuk bertanya pada temannya sehingga ada rasa ingin bekerjasama antar siswa. Salah satu model pembelajaran yang dapat diterapkan guna meningkatkankeikutsertaan siswa secara aktif dalam pembelajaran adalah menerapkanpembelajaran kooperatif. Dalam kooperatif masing-masing kelompok akan bertanggung jawabterhadap keberhasilan diri dan anggotanya.

Berdasarkan permasalahan di atas, salah satu upaya yang dapat dilakukan dalam penelitian ini adalah dengan menerapkan model pembelajaran kooperatif tipe Numbered Head Together. Metode Numbered Head Together (NHT) merupakan aplikasi dari pembelajaran kooperatif(Cooperatif Learning). NHT dikembangkan oleh Spencer Kagan(1992). Metode ini memberikan kesempatan kepada siswa untuk saling membagikan ide-ide dan mempertimbangkan jawaban yang paling tepat terhadap pertanyaan atau masalah yang sedang dihadapi. Langkah-langkah yang dilakukan guru dalam pembelajaran kooperatif dengan metode ini menurut Ibrahim,dkk(2009:28) ada empat langkah yaitu penomoran (Numbering), mengajukan pertanyan (Questioning), berfikir bersama (Head Together), dan menjawab (Answering).

Agnafia (2011:6) menjelaskan bahwa: Pembelajaran kooperatif tipe Numbered Head Together menuntut siswa untuk terlibat aktif dalam proses pembelajaran dan memiliki tanggung jawab penuh dalam memahami materi pembelajaran baik secara individumaupun secara kelompok. Pembelajaran dengan menggunakan tipe NHT ini dapat melatih siswa untuk saling berbagi informasi, mendengar dengan cermat serta berbicara sesuai pendapat mereka masingmasing, sehingga siswa dapat lebih aktif dalam pembelajaran.

Penerapan pembelajaran NHT maka akan tercipta suasana koordinasi dimana siswa akan saling berkomunikasi, saling mendengarkan, saling berbagi, saling memberi dan menerima dan keadaan tersebut akan memupuk jiwa, sikap, dan perilaku yang pada akhirnya mampu membawa dampak positif berupa peningkatan hasil belajar sebagai salah satu indikator keberhasilan yang dilakukan.

Uraian-uraian diatas membuat peneliti menganggap perlu untuk mengadakan penelitian dengan judul "Pengaruh Penggunaan Metode Numbered Head Together Terhadap Hasil Belajar Matematika Siswa Kelas VII MTs. NW Bonjeruk Tahun Pelajaran 2016/2017”.

Rumusan masalah pada penelitian ini adalah apakah adapengaruh metode numbered head together (NHT) terhadap hasil belajar Matematika siswa kelas VII MTsNW Bonjeruk pada tahun 2016/2017?

Adapun tujuan adanya penelitian ini adalah untuk mengetahui pengaruh penggunaan metode numbered head together(NHT) terhadaphasil belajar Matematika siswa kelas VII MTsNW Bonjeruk pada tahun 2016/2017.

Metode pembelajaran kooperatif adalah salah satu metode pembelajaran yang dilakukan secara berkelompok dan 
mengutamakan kerjasama diantara siswa untuk mencapai tujuan pembelajaran.

Metode Numbered Head Together (NHT) dalam penelitian ini adalah pembimbingan atau pelajaran yang diberikan oleh seorang siswa kepada yang lain, sedangkan mereka adalah teman sekelas atau sebangku yang usianya relatif sama (yang berperan sebagai pembimbing dengan yang dibimbing adalah antar sesama siswa).

Pembelajaran adalah sebuah proses yang bertujuan membantu seseorang untuk belajar, bagaimana melakukan sesuatu, memberikan interaksi, memberikan hubungan dalam dalam mempelajari sesuatu, memberikan ilmu pengetahuan, dan memberikan pemahaman kepada siswa (Syahrir, 2010:3).

Dari sudut pandang sosiologis, proses pembelajaran adalah proses pembelajaran peserta didik untuk dapat menjalankan kehidupannya dimasyarakat.Numbered Head Together berasal dari dua kata yaitu"Numbering"dan "Head Together". Numbering artinya penomoran head together berarti menyatukan kepala. Dengan demiikian dapat diambil pengertian bahwa Numbered Head Together adalah pembelajaran yang diawali dengan penomoran kemudian kelompok-kelompok kecil yang selanjutnya tiap-tiap kelompok diberikan kesempatan untuk menyatukan kepala berdiskusi memecahkan masalah-masalah dalam pembelajaran kemudian guru memanggil nomor yang dipegang oleh siswa secara acak (Masjudin, 2016:76-84).

Strategi pembelajaran kooperatif tipe Numbered Head Together merupakan jenis pembelajaran yang dirancang untuk mempengaruhi pola interaksi siswa dan sebagai alternatif terhadap kelas tradisional. Strategi pembelajaran ini dikembangkan untuk membangun kelas sebagai komunitas belajar yang menghargai semua kemampuan siswa (Hidayah, Nurul, Rustiana, dan Ismiyati, 2012).

Pembelajaran kooperatif tipe NHT menurut Slavin dalam Isjoni (2012) adalah suatu model embelajran dimana siswa dalam kelompok kecil, siswa belajar dan bekerja secara kolboratif dengan struktur kelompok yang heterogen. Tujuan pembelajaran kooperatif adalah untuk meningkatkan partisipasi siswa dan mempersiapkan siswa agar memiliki sifat kepemimpinan. Langkahlangakah pembelajaran Numbered Head Together

Ibrahim mengembangkan langkahlangkah pembelajaran kooperatif tipe NHT menjadi enam langkah (Herdian, 2009) yaiu sebagai berkut:(1) Penomoran,Dalam fase ini guru membagi siswa kedalam kelompok 3-5 orang, dan kepada setiap anggota kelompok diberi nomor sesuai jumlah kelompok. (2) Mengajukan pertanyaan, Guru mengajukan suatu pertanyaan kepada siswa. (3) Berpikir bersama, Siswa menyatukan pendapatnya terhadap jawaban pertanyaan itu, dan meyakinkan tiap anggota timnya mengetahui jawaban tim.(4) Menjawab, Guru memanggil suatu nomor tertentu, kemudian siswa yang nomornya sesuai mengacungkan tangannya dan mencoba untuk menjawabpertanyaan untuk seluruh kelas.

Hasil belajar adalah kemampuankemampuan yang dimiliki siswa setelah ia menerima pengalaman belajarnya. Hasil belajar mencakup kemapuan kognitif, efektif dan psikomotorik. Yang harus di ingat, hasil belajar adalah perubahan perilaku secara keseluruhan bukan hanya salah satu aspek potensi kemanusiaan saja. Artinya, hasil pembelajaran yang dikategorisasi oleh para pakar pendidikan sebagaimana tersebut diatas tidak dilihat secara fragmentaris atau terpisah, melainkan kompherensif (Suprijono, 2011).

Menurut Dimyati dan Mudjiono (2006), hasil belajar merupakan hal yang dapat dipandang dari dua sisi yaitu sisi siswa dan dari sisi guru. Hasil belajar merupakan tingkat perkembangan mental (terwujud dalam jenisjenis ranah kognitif,afektif dan psikomotor) yang lebih baik bila dibandingkan pada saat sebelum belajar jika dilihat dari sisi siswa, namun jika dilihat dari sisi guru hasil belajar merupakan saat terselesikannya bahan pelajaran. Hasil belajar merupakan proses dalam diri individu yang berinteraksi dengan lingkungan untuk mendapatkan perubahan dalam perilakunya (Purwanto. 2010). Nana Sudjana (2009) mengatakan bahwa hasil belajar siswa hakikatnya adalah perubahan tingkah laku, yang mencakup bidang kognitif, afektif dan psikomotorik. 


\section{METODOLOGI PENELITIAN}

Penelitian ini dilakukan di kelas VII pada semester genap di MTs. NW Bonjeruk tahun Pelajaran 2016/2017.Jenis penelitian ini merupakan jenis penelitian eksperimen. Dalam penelitian eksperimen ada perlakuan (treatmen) yang berfungsi sebagai variabel, sengaja diadakan pada satu obyek untuk diketahui pengaruh atau akibatnya dalam bentuk varibel terikat yang muncul karena perlakuan itu. Dengan kata lain metode eksperimen dapat diartiakan sebagai suatu cara untuk mencari hubungan sebab akibat (hubungan kasual) antara dua faktor yang sengaja ditimbulkan oleh peneliti dengan mengeliminasi atau mengurangi atau menyisihkan faktor-faktor lain yang mengganggu yang dilakukan untuk melihat akibat dari suatu perlakuan (Arikunto, 2010:9).

Menurut (Sugiyono, 2014:7) penelitian eksperimen adalah suatu penelitian yang berusaha mencari pengaruh variabel tertentu terhadap variabel yang lain dalam kondisi yang terkontrol secara ketat.Selanjutnya karena jenis penelitian yang tidak dapat sepenuhnya mengontrol variabel-variabel luar yang mempengaruhi jalanya eksperimen maka penelitian ini merupakan penelitian quasieksperiment (eksperimen semu). Ciri utama dari quasi eksperiment adalah bahwa sampel yang digunakan untuk eksperimen maupun kelompok kontrol tidak diambil secara random/ acak dari suatun populasi tertentu.

Adapun Rancangan penelitian merupakan keseluruhan proses penelitian dan penentuan yang berlangsung tentang hal-hal yang dilakukan.Menurut Sugiyono (2010) rancangan penelitian yang akan digunakan adalah prettes-posttesgroup Design. Adapun desain penlitian ini seperti yang terlihat pada tebel 2.1 sebagai berikut:

Tabel 3.1. RancanganPenelitianPrettesPosttes Control Group Design

\begin{tabular}{|l|c|c|c|}
\hline Kelompok & Pretest & Perlakuan & Posttest \\
\hline Eksperimen & $\mathrm{O}_{1}$ & $\mathrm{X}$ & $\mathrm{O}_{3}$ \\
\hline Kontrol & $\mathrm{O}_{2}$ & $\mathrm{O}$ & $\mathrm{O}_{4}$ \\
\hline
\end{tabular}

Keterangan:

$\mathrm{O}_{1}$ : Pemberian tes awal pada kelas kontrol
$\mathrm{O}_{2}$ : Pemberian tes awal pada kelas kontrol

$\mathrm{O}_{3}$ : Pemberian tes akhir pada kelas eksperimen

$\mathrm{O}_{4}$ : Pemberian tes akhir pada kelas kontrol

$\mathrm{X}$ : perlakuan dengan model pembelajaran kooperatif tipe NHT

$\mathrm{O}$ : pembelajaran konvensial

Adapun Teknik pengumpulan data yang dilakukan dalam penelitian ini adalah:(1)Sumber data, Sumber data penelitian adalah dari tes yang diberikan kepada siswa kelas VII MTs. NW Bonjeruk Lombok Tengah tahun pelajaran 2016/2017.(2) Jenis data yang digunakan adalah data kuantitatifyang terdiri dari data hasil pre-test siswa dan hasil post-test metode Numbered Head Together.(3) Cara pengambilan data adalah dengan mengambil hasil pre-test dan post-test berupa soal-soal.

\section{HASIL DAN PEMBAHASAN}

\section{A. Hasil Penelitian}

Penelitian ini dilaksanakan di MTs NW Bonjeruk dari tanggal 12 Februari sampai dengan tanggal 12 Maret 2017. Adapun hasil penelitian yang diperoleh sebagai berikut.

\section{Data Hasil PreTest}

Data hasil pretest digunakan untuk mengetahui kemampuan awal siswa kelas kontrol dengen kelas eksperimen. Dari data hasil pretest yang diberikan kepada kelas eksperimen dan kelas kontrol terdapat pada lampiran 01 dan lampiran 02. Diperoleh nilai sebagaimana yang tercantum pada tabel di bawah ini.

Tabel 4.1 Hasil Pretest Kelas Eksperimen dan Kelas Kontrol

\begin{tabular}{|c|l|c|c|}
\hline No. & \multicolumn{1}{|c|}{ Data } & Eksperimen & Kontrol \\
\hline 1 & $\begin{array}{l}\text { Nilai } \\
\text { tertinggi }\end{array}$ & 80 & 75 \\
\hline 2 & $\begin{array}{l}\text { Nilia } \\
\text { terendah }\end{array}$ & 60 & 50 \\
\hline 3 & Rata-rata & 69 & 65 \\
\hline & $\begin{array}{l}\text { Jumlah } \\
\text { siswa }\end{array}$ & 14 & 13 \\
\hline
\end{tabular}

Tabel yang ada di atas menjelaskan hasil pretest. Nilai terendah pada kelas eksperimen adalah 60 dan kelas kontrol terendah 50. Untuk nilai tertinggi pada kelas eksperimen adalah 80 dan nilai tertinggi pada kelas kontrol adalah 75 kemudian nilai rata- 
rata pada kelas eksperimen 69 dan nilai ratarata pada kelas kontrol 65 .

\section{Data Hasil Posttest}

Data hasil posttest digunakan untuk mengetahui kemampuan setelah perlakuan antara kelas kontrol dan kelas eksperimen. Data hasil posttest kelas eksperimen dan kelas kontrol diperoleh hasil seperti tabel 4.2 berikut.

Tabel 4.2. Hasil Posttest Siswa Kelas Eksperimen dan Kelas Kontrol

\begin{tabular}{|c|l|c|c|}
\hline No. & \multicolumn{1}{|c|}{ Data } & Eksperimen & Kontrol \\
\hline 1 & Nilai tinggi & 85 & 80 \\
\hline 2 & $\begin{array}{l}\text { Nilai } \\
\text { rendah }\end{array}$ & 70 & 70 \\
\hline 3 & Rata-rata & 78 & 76 \\
\hline & $\begin{array}{l}\text { Jumlah } \\
\text { siswa }\end{array}$ & 14 & 13 \\
\hline
\end{tabular}

Tabel di atas menjelaskan tentang hasil posttest. Nilai terendah pada kelas eksperimen 70 dan nilai terendah pada kelas kontrol 70. Untuk nilai tertinggi kelas eksperimen 85 dan nilai tertinggi pada kelas kontrol adalah 80 .

\section{Uji Normalitas}

Hasil uji normalitas data pretest kelaskontrol.

Berdasarkan hasil perhitungan diperoleh hasil 0,159 denga signfikansi 0,200>0,05 dengan demikian data hasil pretest berdistribusi normal. Artinya, hasil perhitungan dengan menggunakan rumus Kolmogorov-Smirnov diperoleh 0,159 dan diperoleh taraf signifikansi 0,200. Karena signfikansi hasil perhitungan lebih besar dari pada besar dari pada signifikasi 0,05 , maka dapat disimpulkan bahwa data memiliki distribusi normal.

\section{Hasil uji normalitas data pretest} kelaseksperimen.

Berdasarkan hasil perhitungan di atas, diperoleh hasil 0,207 dengan signfikansi 0,107>0,05 dengan demikian data hasil pretest berdistribusi normal.

Hasil perhitungan normalitas posttest kelas kontrol

Berdasarkan hasil perhitungan di atas, diperoleh hasil 0,232 dengan signfikansi $0,53>0,05$ dengan demikian data hasil posttest kelas kontrol berdistrbusi normal.

\section{Hasil perhitungan normalitas posttest kelas eksperimen}

Berdasarkan hasil perhitungan di atas, diperoleh hasil 0,188 dengan signfikansi 0,192>0,05 dengan demikian data hasil posttest kelas eksperimen berdistribusi normal. Dengan demikian kedua sampel baik kelas kontrol dengan sampel kelas eksperimen memiliki distribusi distribusi normal.

\section{Uji homogenitas}

Uji homogenitas adalah untuk membuktikan kebenaran hipotesis yang telah dibuat sebelumnya, maka perlu diuji varians kedua sampel atau tidak.

\section{Hasil perhitungan homogenitas kelas kontrol}

Berdasarkan hasil perhitungan di atas, diperoleh hasil 2,457 dengan signfikansi 0,149>0,05 dengan demikian data hasil pretestdan posttest kelas kontrol berdistribusi homogen. Artinya, signifikansi 0,149 lebih besar dengan signifikansi 0,05 , sehingga $\mathrm{H} 0$ diterima. Jadi, data berasal dari populasi yang homogen.

\section{Hasil Pengujian Homogenitas Kelas Eksperimen}

Berdasarkan hasil perhitungan di atas, diperoleh hasil 2,887 dengan signfikansi 0,087>0,05 dengan demikian data hasil pretestdan posttest kelas eksperimen berdistribusi homogen. Dengan demikian dapat dikatakan kedua sampel, yaitu kelas eksperimen dan kelas kontrol memiliki kemampuan yang homogen.

\section{Pengujian hipotesis}

Berdasarkan hasil analisis data di atas, diperoleh $\mathrm{t}$ hitung 7,41 dan $\mathrm{t}$ tabel pada $\mathrm{dk}=$ $\mathrm{n}-2=27-2=25$ dengan taraf signifikansi $5 \%$ dan diperoleh $\mathrm{t}$ tabel sebesar 2,06 dengan demikian t hitung $>\mathrm{t}$ tabel. Artinya hipotesis Ho ditolak dan Ha diterima dengan kata lain ada pengaruh metode numbered head together (NHT) terhadap hasil belajar Matematika siswa kelas VII MTs NW Bonjeruk tahun pelajaran 2016/2017.

\section{PEMBAHASAN}

Berdasarkan hasil analisis data di atas, diperoleh $\mathrm{t}$ hitung 7,41 dan $\mathrm{t}$ tabel pada $\mathrm{dk}=$ $\mathrm{n}-2=27-2=25$ dengan taraf signifikansi $5 \%$ dan diperoleh $\mathrm{t}$ tabel sebesar 2,06 dengan demikian t hitung $>\mathrm{t}$ tabel. Artinya hipotesis Ho ditolak dan Ha diterima dengan kata lain 
ada pengaruh metode numbered head together (NHT) terhadap hasil belajar Matematika siswa kelas VII MTs NW Bonjeruk tahun pelajaran 2016/2017.

Penelitian yang telah dilaksanakan dengan menggunakan metode numbered head together (NHT) siswa lebih memiliki semangat dan termotivasi dalam belajar. Penyebab lain pada pembelajaran dengan menggunakan metode numbered head together (NHT) adalah siswa yang belajar siap karena memiliki nomor sesuai dengan kelompoknya dan siswa dalam melaksanakan diskusi dengan cara bersungguh-sungguh. Faktor lain yang menyebabkan metode numbered head together (NHT) memiliki prestasi belajar yang lebih tinggi dibandingkan dengan menggunakan metode pembelajaran konvensional atau ceramah adalah siswa yang memiliki pahaman lebih atau pandai dapat mengajari temannya yang memiliki pengetahuan yang kurang.

Penjelasan yang ada di atas, sesuai dengan Herdian (2009) yang menjelaskan kelebihan metode numbered head together (NHT) adalah semua siswa menjadi siap belajar, siswa dapat melakukan dengan sungguh, dan siswa yang pandai dapat mengajarkan pada siswa yang kurang pandai.

Lebih lanjut ahli lain menjelaskan tentang penyebab pembelajaran dengan menggunakan metode numbered head together (NHT) lebih bagus dibandingkan dengan menggunakan metode pembelajaran konvensional atau metode ceramah adalah memperbaiki kehadiran siswa, penerimaa terhadap individu lebih besar, perilaku untuk mengganggu lebih kecil, konflik antar pribadi berkurang, pemahaman yang lebih mendalam, meningkatkan kebaikan budi, kepekaan dan toleransi dan hasil belajar lebih tinggi (Ibrahim, 2000).

Metode pembelajaran memberikan dampak terhadap hasil pembelajaran guru yang mengajar hanya dengan menggunakan metode konvensional seperti guru hanya mengajar dengan menggunakan metode ceramah, maka akan memuncul striotipe pada siswa. Oleh sebab itu, guru dalam mengajar dituntut untuk mengadakan pengembangkan metode agar siswa yang belajar tidak bosan dan dapat menghasil kualitas pembelajaran yang lebih bermakna.

Agar pembelajaran lebih bermakna maka guru mengembangkan metode pembelajaran yang lebih inovatif. Menurut Slavin (dalam Isjoni, 2012) adalah suatu model pembelajaran dimana siswa dalam kelompok kecil, siswa belajar dan bekerja secara kolaboratif dengan struktur kelompok yang heterogen. Pada ahli lain menjelaskan kelebihan yang dimiliki metode pembelajaran dengan menggunakan numbered head together (NHT) adalah (a) semua siswa menjadi siap, (b) siswa dapat melakukan diskusi dengan sungguh-sungguh, (c) siswa yang pandai dapat mengajari siswa yang kurang pandai.

Penerapan pembelajaran dengan menggunakan metode pembelajaran numbered head together (NHT) akan menjadikan siswa tidak hanya melakukan pembelajaran dengan satu arah melainkan siswa akan ikut berperan aktif dalam proses pembelajaran, melalui pembelajaran ini siswa tidak akan bosan dan akan merasa menyenangkan pada saat belajar, karena siswa tidak hanya berpikir sendiri dalam memecahkan masalah melainkan dapat bertukar pikiran dengan teman kelompok mereka, disamping itu juga metode pembelajaran dengan menggunakan metode numbered head together (NHT) akan menjadikan siswa yang tadinya pasif menjadi aktif karena dengan adanya pemberian nomor masing-masing individual akan memiliki tanggung jawab dan dapat meningkatkan rasa percaya diri pada masing-masing siswa (Hidayah,dkk, 2012).

Berdasarkan hasil analisis data dan kajian teori yang ada di atas, dapat disimpulkan pembelajaran dengan menggunakan metode numbered head together (NHT) dapat meningkatkan hasil belajar siswa kelas VII di MTs NW Bonjeruk tahun pelajaran 2016/2017.

\section{Kesimpulan}

Berdasarkan hasil analisis data dan pembahasan dalam penelitian ini dapat diambil kesimpulan, bahwa ada pengaruh metode numbered head together (NHT) terhadap hasil belajar Matematika siswa kelas VII MTs NW Bonjeruk tahun pelajaran 
2016/2017. Hal ini terbukti dengan hasil uji hipotesis dengan t-test diperoleh t hitung 7,41 dan t tabel pada $\mathrm{dk}=\mathrm{n}-2=27-2=25$ dengan taraf signifikansi 5\% dan diperoleh $\mathrm{t}$ tabel sebesar 2,06 dengan demikian $\mathrm{t}$ hitung $>\mathrm{t}$ tabel. Artinya hipotesis Ho ditolak dan $\mathrm{Ha}$ diterima dengan kata lain ada pengaruh metode numbered head together (NHT) terhadap hasil belajar Matematika siswa kelas VII MTs NW Bonjeruk tahun pelajaran 2016/2017.

\section{SARAN}

Berpedoman pada hasil yang dicapai dalam penelitian ini, maka saran-saran yang dapat disampaikan dalam penelitian ini adalah

1. Untuk guru

Diharapkan kepada guru di MTs NW Bonjeruk untuk terus mengembangkan metode pembelajaran agar hasil belajar siswa dapat meningkat.

2. Untuk sekolah

Diharapkan kepada sekolah untuk mengadakan pelatihan atau workshop penggunaan metode pembelajaran agar guru terlatih menggunakan metode pembelajaran baru.

3. Untuk mahasiswa

Diharapkan bagi para peneliti berikutnya untuk memperhatikan materi pelajaran yang akan digunakan untuk mengadakan penelitian.

\section{DAFTAR PUSTAKA}

Arikunto, S. 2010. Prosedur Penelitian Suatu Pendekatan Praktik. Jakarta: PT. Rineka Cipta.

Agnafia, D.N. (2011). Penerapan embelajaran Kooperatif Tipe Numbered Heads Together (NHT) Melalui Media Cd Interaktif Untuk Meningkatkan Motivasi Belajar. Universitas Sebelas Maret Surakarta

Dimyanti dan Mudjiono. 2006 Belajar dan Pembelajaran. Jakarta : Rineka Cipta

Herdian, 2009. Model Pembelajaran Numered Head Together(online) http://herdy07.wordpress.com/2009/0 4/22/model-pembelajaran-nhtnumberd-head-together/feed/.

Hidayah, Ismiyati, Nurul.L, Rustiana. A, 2012 peningkatan hasil belajar menggunakan peralatan kantor melalui Model pembelajaran kooperatif Tipe NHT. Econmic education analysis journal.

Semarang.

Isjoni. 2011.Cooperatif Learning(efektif Pembelajaran Kelompok). Bandung : Alfabeta.

Ibrahim. 2009. Pembelajaran Kooperatif. Surabaya:University Press.

Masjudin. 2016 PembelajaranCooperatif InvestigativeUntuk Meningkatkan Pemahaman Siswa Materi Barisan dan Deret. IKIP Mataram.

Sugiyono. 2014. Metode Penelitian Kuantitatif, Kualitatif, dan $R \& D$. Bandung: Alfabeta.

Suprijono. A.2009. Cooperatif Learning Teori dan Aplikasi Paikem. Yogyakara:Pustaka Belajar

Syahrir. 2010. Metodologi Pembelajaran Matematika. Yogyakarta: Naufan Pustaka

Slavin. R., E. 2011. Cooperatif Learning. Teori, Riset dan Praktik. Bandung: Penerbit Nusa Media. 